\title{
Studies on the succession of major insect pests of okra and their correlation with weather parameters
}

\author{
Satyarth Harinkhere*, A.S., Thakur, R. Pachori and S.B. Das
}

Department of Entomology, Jawaharlal Nehru Krishi Vishwa Vidyalaya, Jabalpur (M.P.) India

\section{ARITCLE INFO}

Received : 23.07.2018

Revised : 11.09 .2018

Accepted : 24.09 .2018

KEY WORDS :

Aphids, Jassids, Whitefly, Green stink bug, Red spider mite, Whitefly, Jassid, Red cotton bug, Shoot, Fruit borer

*Corresponding author:

\begin{abstract}
An experiment was conducted to observe the studies on the major insect pests of okra during Kharif season of 2011 at Department Of Entomology, Live Stock Farm, Adhartal, J.N.K.V.V. Jabalpur (M.P.). Jassids and whitefly incidence was observed from 27 DAS (16 September 2011) to 90 DAS (18 November 2011) with one distinct peak, respectively during 44 SMW with mean population (nymph + adult) per 30 leaf was 26.11 for jassids and 25.6 for whitefly. While initation of fruit infestation by shoot and fruit borer recorded at $41 \%$ SMW (01-07 Oct 2011) and epidemic at 41 SMW (08-14 Oct. 2011) with 35.35 per cent.
\end{abstract}

How to view point the article : Harinkhere, Satyarth, Thakur, A.S., Pachori, R. and Das, S.B. (2018). Studies on the succession of major insect pests of okra and their correlation with weather parameters. Internat. J. Plant Protec., 11(2) : 164-168, DOI : 10.15740/HAS/IJPP/11.2/164-168, Copyright@ 2018: Hind Agri-Horticultural Society. 